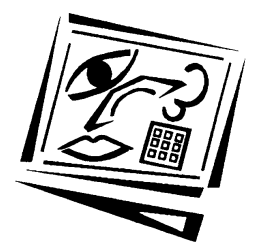

\title{
Design and evaluation of two blended learning approaches: Lessons learned
}

\author{
Wing Sum Cheung and Khe Foon Hew \\ Nanyang Technological University
}

\begin{abstract}
In this paper, we share two blended learning approaches used at the National Institute of Education in Singapore. We have been using these two approaches in the last twelve years in many courses ranging from the diploma to graduate programs. For the first blended learning approach, we integrated one asynchronous communication tool with face to face tutorials, classroom discussions, and a reflection session. For the second blended learning approach, we integrated two asynchronous tools with face to face tutorials in a course. We discuss the theoretical foundation of the two blended learning approaches. In addition, we share insights from these two blended learning approaches, based on the students' data (online postings, questionnaires, reflection logs, and interviews), as well as our own reflections. Finally, we describe and discuss several important lessons learned that could inform the design of future instructional strategies in implementing blended learning in university teaching and learning settings.
\end{abstract}

\section{Introduction}

In the last decade, the blended learning approach has been adopted widely in schools, universities and training sections in the business world. One of the major reasons this approach is gaining momentum is due to teachers and instructors not using online learning to completely replace traditional face to face classroom teaching, but to complement or overcome some of the short comings of face to face teaching. This combination of the online learning and face to face approaches is called blended learning (Reay, 2001; Rooney, 2003; Graham, 2006). Many universities are currently using the blended learning approach for various purposes such as increasing the number of students enrolled (Dziuban, Hartman, Juge, Moskal \& Sorg, 2006), and to provide an effective way to communicate with students (Borup, Graham \& Velasquez, 2006). For example, Dziuban et al. (2006) reported that blended learning courses at the University of Central Florida were popular with students, and that enrolments rose from 125 in 1997 to more than 13,600 in 2003-2004. Why is this so? It appears that blended learning is able to meet the educational needs of students. Since many students have work and family responsibilities, blended learning helps provide the flexibility that students require (McCray, 2000; Strambi \& Bouvet, 2003; Wingard, 2004). It is therefore not surprising that blended learning plays an important factor in determining whether students enroll in and complete a program of study.

Blended learning can also improve communication with students. Blended learning can offer a higher level of interaction than commonly experienced in face to face courses (Dziuban, Hartman \& Moskal, 2004; Wingard, 2004). This is because the various technology tools available in many blended courses and learning management 
systems combine to form a communication environment with features such as facilitating access to course materials and experts that might not be otherwise available (Dziuban et al., 2004). Furthermore, some research studies have found that blended learning can improve student learning outcomes while lowering student attrition rates. For example, although success rates varied between disciplines, blended courses generally produced successful student learning outcome rates (those students achieving an $A, B$, or $C$ ) equal to or higher than their face to face and fully online counterparts (Dziuban et al., 2004). Overall, the attrition rates for blended courses were also generally comparable to those in face to face courses (Dziuban et al., 2004; 2006).

Due to the aforementioned potential benefits, it is therefore not surprising that many institutions have implemented or considering implementing blended learning in their programs. As Graham (2006, p. 7) wrote, "we can be pretty certain that the trend toward blended learning systems will increase." However, it is important to note that the success of blended learning does not happen automatically. A key factor in successful blended learning is considering the pedagogy and instructional design associated with how best to utilise the technology tools, how to facilitate interactions among students, how to motivate students to participate in the discussions, as well as what contents are best delivered through the Internet versus face to face (Dziuban et al., 2006).

In this paper, we share two blended learning approaches used at the National Institute of Education (NIE) in Singapore. We have been using these two approaches in the last twelve years in many various courses ranging from the diploma to graduate programs. For the first blended learning approach, we integrated one asynchronous communication tool with face to face tutorials, classroom discussions, and a reflection session. For the second blended learning approach, we integrated two asynchronous tools with face to face tutorials in a course. We discuss the theoretical foundations of the two blended learning approaches, share insights into these two blended learning approaches based on the students' data (e.g., online postings, questionnaires, reflection logs, and interviews), and our own reflections, as well as discuss several important lessons learned that could inform the design of future instructional strategies in implementing blended learning in university teaching and learning settings.

\section{Use of technology in blended learning}

In blended learning, instructors typically use computer technology with Internet access. The blended learning environment may be as simple as providing administrative information, reading materials, and resources for the students. However, some teachers and instructors enable students to interact with each other by using asynchronous and synchronous communication technologies. Asynchronous communication is defined as "instruction and / or communication that takes place at different times, in different locations, eliminating obstacles related to time and travel constraints" (Fenton \& Watkins, 2010, p. 233). Synchronous communication is defined as "instruction and / or communication that occurs in real time, whereby students and instructor exchange information at the same time and, most likely from different locations" (Fenton \& Watkins, 2010, p. 240). Most of teachers and instructors prefer to use asynchronous technologies to synchronous tools (Hew, Cheung \& Ng, 2010; Romiszowski \& Mason, 2004). This is because asynchronous technologies offer students the flexibility of communication at their own pace. Such flexibility provides students more time to reflect on their own as well as other students' or tutor's comments (Murphy \& Coleman, 2004) as compared to synchronous communication. 
In NIE, many of our courses have been conducted via face to face classroom teaching, along with asynchronous online discussion activities. Face to face classroom teaching usually refers to the instructional didactic instructional approach. This approach mainly involves the instructor presenting new knowledge, and / or conducting demonstrations during class time. However, this approach may have the following drawbacks: there is not enough time for students to think deeply about a particular issue, it is difficult for the instructor to direct questions to individual students, and there are limited opportunities for students to interact or receive feedback from other students (Almasi, 1996; Hew \& Cheung, 2003; Wong, Hew \& Cheung, 2009).

The use of asynchronous online discussions could help alleviate some of these drawbacks. The time-delayed interaction could help students develop thinking skills, solve ill-structured problems (Hew \& Knapczyk, 2007), allow more time for students to construct meaning together, as well as greater opportunities for students to receive feedback from their peers.

\section{Theoretical foundation for asynchronous online discussion}

The principles of social constructivism give a theoretical foundation for asynchronous online discussion. In essence, an individual learns through sharing, interacting, and negotiating ideas with other individuals. As a result, an individual can reach a higher cognitive level. During the discussion activity, the individual may construct, reconstruct, and co-construct new ideas. When an individual improves his or her actual cognitive level to a higher level through the interacting with others, it is described as the "Zone of Proximal Development" (Vygotsky, 1978). In the following sections, we present the two blended learning approaches ('Model 1' and 'Model 2') used at the National Institute of Education in Singapore.

\section{Model 1: Face to face tutorials with one asynchronous online discussion activity}

\section{Theoretical framework for Model 1}

This model is based on the GNOSIS framework to integrate constructive and didactic instructional approaches (Hung, Chen \& Cheung, 1998a; 1998b). According to this framework, students are provided with seed ideas and strategies through which they construct knowledge by interacting with others.

These seed ideas and strategies serve as a catalyst for students to construct new knowledge. They are provided with opportunities in generating, negotiating, organising, and situating ideas and strategies so that they could be engaged in the discovery of personalised and new knowledge (Figure 1). The teacher's role is to provide seed ideas and strategies to the students. Students are expected to be involved in the discussion which includes generating new ideas and strategies, negotiating the ideas and strategies for establishing shared meaning, organising their own knowledge, including ideas and strategies developed through their discourse and personal experimentations, and situating their learning into authentic tasks and situations.

\section{Description of Model 1}

At the National Institute of Education, Singapore (NIE), we currently provide a core information and communications technology (ICT) course for all pre-service teachers. 


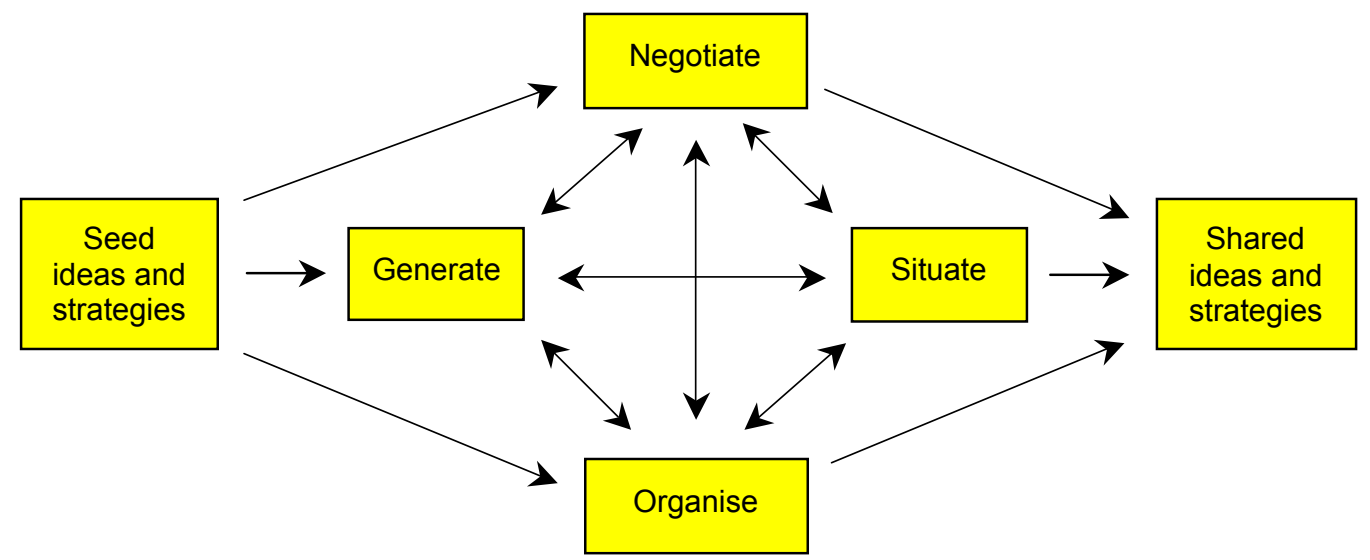

Figure 1: GNOSIS framework adopted from Hung et al. (1998a)

It is a two hours per week face to face tutorial course that runs for 12 weeks, in which they learn how to use computer technology to engage students in learning. Before the students begin the discussion, the tutor provides them some factual information, concepts, and theories about the topic in the face to face tutorials. Often the tutor also provides reading materials for students. A didactic instructional approach is usually employed to introduce the topic and highlight some relevant issues with relevant reading materials (i.e., seed ideas and strategies). The didactic approach is usually followed by face to face classroom discussions. However, such discussions are limited by the following factors.

Face to face classroom discussions tend to revolve around the tutor. It is typically characterised by the Initiate-Respond-Evaluate structure. Consequently, students may have limited opportunities to interact with their peers. Secondly, due to timetabling limitations, a tutor usually does not have enough time for allowing students to think and discuss some important topics related to technology integration.

To help overcome these limitations, the tutor continues the discussion outside the classroom through the means of online discussion forums. The tutor posts the online topics or pertinent questions. At the end of the online discussion activity, the follow up instructional activities may be a reflection log or a project. We summarise the overview of Model 1 in Figure 2. To have a better understanding of the details of Model 1, we summarise the instructional mode, instructional activities and GNOSIS Process Steps in Table 1.

Here are some examples of the questions that a tutor may use in the online discussion activity.

- How can problem based learning be made useful with ICT?

- How can online forums be used for teaching in your own area such as Chinese, mathematics, and English?

- How would you use ICT in a problem based learning lesson to enhance student learning / thinking? 


\section{Evaluation of Model 1's effectiveness from the tutor's perspective}

In 2000, we began to integrate asynchronous online discussion activities into our face to face tutorials. Initially, we were the facilitators of the asynchronous online discussion activity. When we evaluated the model, we realised there were some drawbacks. First, it was a very labour intensive and time consuming task for us to mark all the online postings. Second, we found some students merely "playing the game" of assessment (Oliver \& Shaw, 2003, p. 64). Students simply made postings to earn marks but their contributions were not original or insightful. In other words, their contributions did not really add value to any one's learning. Examples of such posts included, "Yes John, I agree with your idea" or "John, you just share an excellent idea with us".

In 2006, we modified the model to overcome these problems. First, students took turns to be online facilitators rather than the tutors. This cut down the workload for the tutor and allowed the students to learn to play the role of online facilitators. However, training had to be provided for students to prepare them for being online facilitators prior to the actual discussion. To encourage the students to participate and facilitate well in the online discussion environment, marks were awarded.

Second, we required the facilitators to set up ground rules to ensure the responses are supported by sound reason(s) (Cheung \& Hew, 2007). For example, the facilitator of the online discussion activity might set the following ground rule, "if you agree or disagree with anyone in the group, you have to give clear reason(s)". The reason(s) may be based on concepts and / or theories, personal experience, and logic.

Third, we realised that some students could learn a lot simply by reading their peers' postings, but might not contribute many postings of their own in the online discussions. To assess their learning from the face to face tutorials and online discussion activity, we assessed their reflection logs, term paper, and/ or projects. As a result, we did not really need to grade or assess their online postings. For example, students had face to face tutorials to learn about problem based learning with some reading materials. Then they were asked to discuss how problem based learning could be made useful with ICT. After the discussion, they developed a simple problem based learning software package for primary school students. We subsequently assessed the students' knowledge of problem based learning by examining their software package.

Table 2: Reflection questions for pre-service teachers' log

\begin{tabular}{|c|l|}
\hline \multicolumn{1}{|c|}{ Reflection questions } \\
\hline 2 & $\begin{array}{l}\text { Which four facilitation skill(s) did you have the opportunity to demonstrate in your } \\
\text { forum, and why did you apply them in those instances? (Please supply evidence). }\end{array}$ \\
\hline 3 & $\begin{array}{l}\text { Please scan through all the discussion forums in your tutorial class. Find three different } \\
\text { facilitation skills which you learned from your peers? (Please supply evidence) }\end{array}$ \\
$\begin{array}{l}\text { Describe how you would transfer the facilitation skills covered in this module to your } \\
\text { target students. }\end{array}$ \\
$\begin{array}{l}\text { a. State your target class profile; e.g. class, level, stream, subject, general ability. } \\
\text { b. In view of 3a, describe how you would adapt your facilitation approach along the } \\
\text { following dimensions: } \\
\text { - Monitoring and ensuring participation } \\
\text { - Feedback to the learner }\end{array}$ \\
\hline
\end{tabular}


Fourth, as previously mentioned, we wanted the pre-service teachers to learn the role of online discussion facilitators. So how could we assess this? At the end of the course, the pre-service teachers were asked to write a reflection log guided by the following questions (see Table 2). By analysing the reflection data, a tutor could assess how much the pre-service teachers had learned from facilitating their own online discussion activity, as well as by observing how others facilitated theirs.

\section{Evaluation of Model 1's effectiveness from the students' perspective}

For the first blended model, we conducted a study with 13 students who took the ICT core course based on Model 1. We asked them to write additional reflections about the use of asynchronous online discussion in Model 1. About ninety two percent of the students agreed that asynchronous online discussion activity was useful and enjoyable. Here are some of their comments.

\footnotetext{
Student GCM: It provided a platform of idea sharing which I thought was very commendable.

Student NZY: It is useful to a certain extent. It is always refreshing to read differing opinions, new perspectives. The flexibility of participating in online discussion forum anytime anywhere is also a big plus point.

Student HSF: I can better appreciate the viewpoints of others, and it's interesting to see how others respond to different ideas. Through this experience, I believe I can better help my students in future to participate effectively in discussion forums as well.
}

In addition, one student also shared with us that the online discussion activity did help him in his project.

Student PPW: The online discussion has contributed useful feedback to my project ideas.

On the other hand, students listed some cons of using online discussion activity.

Student AS: I did get to learn the challenges of online discussion such as not getting immediate feedback through this discussion forum and the efficacy of it such as the constructive feedback received from fellow peers.

Student SSI; I feel the learning experience has been very useful and enjoyable. It does highlight the possible of the forum being a good tool for peer learning. However, there are some limitations that have to be addressed so as to prevent it's hindrance to discussion.

\section{Contributions of Model 1}

There are a few contributions of Model 1. First, it is an effective way to increase students' learning opportunities by providing the asynchronous online activity. Students learn from each other through the online discussion anywhere and anytime. Second, students are given an equal opportunity to access the asynchronous online discussion environment. Everyone can post his or her views anytime, unlike during face to face session, where usually only one person speaks out at any one time and others have to listen. Sometimes, some students may dominate the face to face discussions. These students are typically the more knowledgeable, or outspoken ones. Consequently, shy, quiet or students who need more time to think before answering often take the backseat in the face to face discussion. 


\section{Model 2: Face to face tutorials with two asynchronous online discussion activities}

\section{Theoretical framework of Model 2}

This blended model is based on the revised Bloom's Taxonomy (see Table 3). The updated Bloom's taxonomy has the following six levels: remembering (recalling information from memory), understanding (constructing meaning from information), applying (using a certain procedure in a given situation), analysing (breaking material into its constituent elements and determining how the elements relate to one another), evaluating (making judgments based on certain criteria), and creating (putting elements together to form something new) (Anderson \& Krathwohl, 2001).

\section{Rationale for Model 2}

We often conduct courses to train pre-service teachers to design instructional resources such as web-based learning materials, and computer-based multimedia learning packages. The courses usually run for 12 to 13 weeks. Based on our experience, we face several challenges in teaching design-based courses. First, students claim that they have learned the design principles and guidelines but they fail to use or apply them in designing their projects. Second, students need time to discuss the projects with their peers and get feedback from them. Due to limited class time, they typically managed to receive only a few feedbacks from their classmates. The aim of Model 2 is to provide a better learning environment to alleviate these problems.

Model 2 differs from Model 1 in two main ways. First, the context in which Model 2 is employed typically is different. Students in Model 2 are involved in solving an illstructured problem, which in this case is a design task or activity. Students in Model 1, on the other hand, are involved in dialogic task such as participating in discussions that centre on course-related issues or topics. Students in Model 1 did not undertake a design activity.

\section{Description of Model 2}

For Model 2, we first provided the face to face tutorials to students. In these we conducted the following tasks in class: ask questions, present new materials, and conduct face to face discussion. Asking questions helps students to recall prerequisite, related learning and helps to assess how much the students have understood from the lecture. Presenting new materials allows students to learn new concepts and principles. Conducting face to face discussions allows the students to discuss with the tutor questions related to the learned concepts and principles. We summarised the overview of Model 2 in Figure 3. To have a better understanding of the details of Model 2, we put the instructional mode, instructional activities, and GNOSIS Process steps in Table 3.

The purpose of the first online discussion activity (online discussion I) was to find out if the students had the ability to apply the learned concepts, theories, and guidelines to critique other people's projects. Students did not know the identity of these people. In a sense, it was a formative evaluation of their understanding of the design topics. The tutor was the facilitator of the first online discussion activity, after which the tutor might give extra help to students who had misconceptions of the design concepts, 
theories, and/ or guidelines. All these learning activities (i.e., face to face tutorials, online discussion I, and extra help for students after the online discussion) aimed to provide a good foundation for before they began to design their own projects.

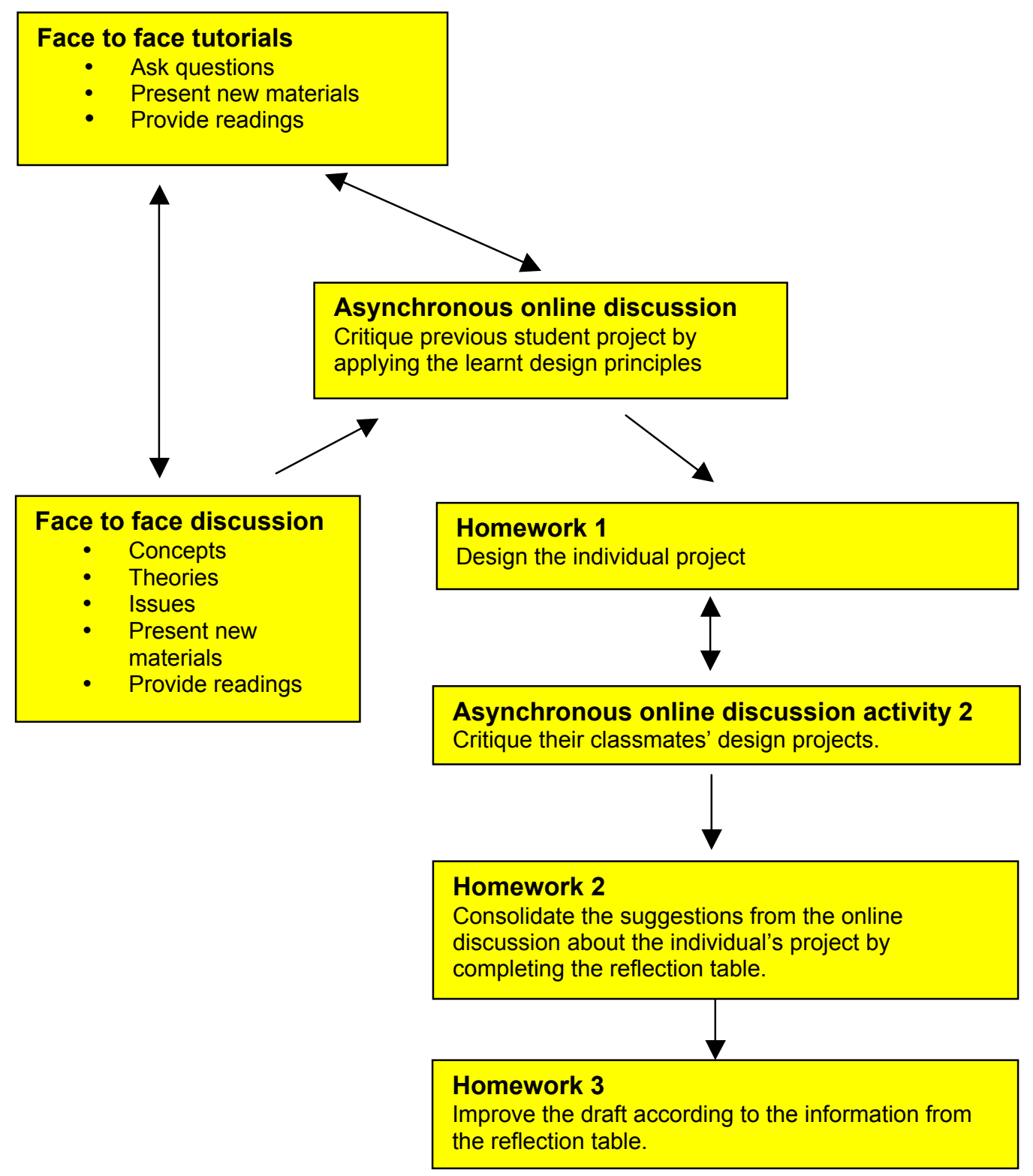

Figure 3: Model 2 overview

After online discussion I had ended, students were asked to create their own projects and upload them unto their own discussion forums. Students were required to critique their peers' projects on the asynchronous online discussion platform (i.e., online discussion II). The purpose of online discussion II was to allow students to get more ideas and suggestions for improving their own projects (Cheung \& Hew, 2004). 
Students were the facilitators for their own forums and they were encouraged to get feedback from their peers. Online discussion II allowed them to discuss problems, solutions, and / or issues related to their own projects.

Table 3: Model 2 details - instructional mode, instructional activities and revised Bloom's Taxonomy

\begin{tabular}{|c|c|c|}
\hline Instructional mode & Instructional activities & Revised Bloom's Taxonomy \\
\hline Face to face tutorials & $\begin{array}{l}\text { Tutor: } \\
\text { - Asked questions } \\
\text { - Presented new materials, and led the } \\
\text { face to face discussion: critique } \\
\text { previous student projects }\end{array}$ & $\begin{array}{l}\text { - Recalling } \\
\text { - Understanding } \\
\text { - Applying } \\
\text { - Analysing } \\
\text { - Evaluating }\end{array}$ \\
\hline $\begin{array}{l}\text { Asynchronous online } \\
\text { discussion activity } 1\end{array}$ & $\begin{array}{l}\text { Tutor: } \\
\text { - Led the online discussion - critique } \\
\text { previous student projects }\end{array}$ & $\begin{array}{l}\text { - Applying } \\
\text { - Analysing } \\
\text { - Evaluating }\end{array}$ \\
\hline Homework 1 & $\begin{array}{l}\text { Student: } \\
\text { - Drafted their design projects }\end{array}$ & - Creating \\
\hline $\begin{array}{l}\text { Asynchronous online } \\
\text { discussion activity } 2\end{array}$ & $\begin{array}{l}\text { Student: } \\
\text { - Uploaded their design projects } \\
\text { - Initiated the online discussion }\end{array}$ & $\begin{array}{l}\text { - Applying } \\
\text { - Analysing } \\
\text { - Evaluating }\end{array}$ \\
\hline Homework 2 & $\begin{array}{l}\text { Student: } \\
\text { - Completed the reflection tables }\end{array}$ & - Evaluating \\
\hline Homework 3 & $\begin{array}{l}\text { Student: } \\
\text { - Used the reflection tables to improve } \\
\text { their projects }\end{array}$ & - Creating \\
\hline
\end{tabular}

After the discussion, each student had to summarise the discussion points in a reflection table (see Table 4). The purpose of the reflection table was to allow each student to consolidate the suggestions and decide how he or she would make use of the suggestions or comments received. Students had to clearly indicate whether they agreed or disagreed with the comments and provide justifications for their decisions. In addition, students had to explain the changes that they intended to make. In short, the reflection table provided the input for students to improve their own designs.

\section{Evaluation of Model 2's effectiveness from the tutor's perspective}

This blended model has been used for various design courses in the last 12 years. There were several advantages of using Model 2, especially for design-related courses. First, students had more time to think. This helped to develop their critical thinking and problem solving skills. In an earlier study, we measured the critical thinking (surface and in depth) of the students in the two online discussion activities (Cheung, Hew \& Foo, 2009). A surface level of critical thinking included the following characteristics: (1) participants making conclusions and judgments without providing any reason or validation; (2) participants sticking to personal prejudices and assumptions; (3) participants agreeing with the remarks and comments by the others without developing their own viewpoint further and; (4) participants failing to suggest the pros and cons of their conclusions, ideas and judgments.

An in depth level of critical thinking, on the other hand, included the following: participants making conclusions and judgments with good reasons and validations provided; (2) participants making informed assumptions based on the available and observable indicators; (3) participants agreeing with remarks and comments by others 
and further developing their own views by assimilating their knowledge and personal experience; and (4) participants stating the pros and cons of their conclusions, suggestions and judgments.

Table 4: Reflection table with sample students' inputs

\begin{tabular}{|c|c|c|c|c|}
\hline & $\begin{array}{c}\text { Suggestions } \\
\text { made by others }\end{array}$ & $\begin{array}{c}\text { My } \\
\text { opinion }\end{array}$ & Rationale & $\begin{array}{l}\text { Changes that I } \\
\text { can/will make }\end{array}$ \\
\hline 1 & $\begin{array}{l}\text { Teacher shouldn't be } \\
\text { present when web activity } \\
\text { is done in school lab. }\end{array}$ & $\begin{array}{l}\text { Agree } \\
\text { strongly }\end{array}$ & $\begin{array}{l}\text { Correct project guideline. } \\
\text { I mistook that the teacher } \\
\text { can be present as long as } \\
\text { they are not involved in } \\
\text { teaching directly. }\end{array}$ & $\begin{array}{l}\text { I will remove the } \\
\text { presence of the teacher } \\
\text { in the lab, in my project } \\
\text { report. }\end{array}$ \\
\hline 2 & $\begin{array}{l}\text { Incentives / rewards } \\
\text { (stickers, etc) for good } \\
\text { work produced (e.g. for } \\
\text { creativity; well-thought } \\
\text { concepts, etc). }\end{array}$ & Agree & $\begin{array}{l}\text { I found that giving } \\
\text { rewards for activities } \\
\text { increases motivation } \\
\text { amongst students (from } \\
\text { personal experience). }\end{array}$ & $\begin{array}{l}\text { I could indicate that } \\
\text { pupils who provide } \\
\text { good understanding in } \\
\text { their worksheet answers } \\
\text { will be rewarded a } \\
\text { sticker. }\end{array}$ \\
\hline 3 & $\begin{array}{l}\text { Change activity to a } \\
\text { revision instead of an } \\
\text { introduction to topic } \\
\text { (because the purpose is to help } \\
\text { students prepare for the final } \\
\text { exams.) }\end{array}$ & Disagree & $\begin{array}{l}\text { Introduction to topics are } \\
\text { a vital part of helping } \\
\text { pupils prepare for the } \\
\text { final exams as basic } \\
\text { concepts learnt in the } \\
\text { introduction are also } \\
\text { tested. }\end{array}$ & $\begin{array}{l}\text { No changes. } \\
\text { I will still keep the web } \\
\text { activity to being an } \\
\text { introduction to the P5 } \\
\text { Science topic of } \\
\text { Materials. }\end{array}$ \\
\hline 4 & $\begin{array}{l}\text { Modify worksheet to } \\
\text { include more items in } \\
\text { addition to "Cup", to test } \\
\text { for suitability of materials } \\
\text { (e.g. school bag/spectacles) }\end{array}$ & $\begin{array}{l}\text { Agree } \\
\text { strongly }\end{array}$ & $\begin{array}{l}\text { By including more } \\
\text { appropriate items, pupils } \\
\text { are able to clearly } \\
\text { understand that more } \\
\text { than } 1 \text { material can be } \\
\text { used to make an item. }\end{array}$ & $\begin{array}{l}\text { I will include at least } \\
\text { another } 1-2 \text { items that } \\
\text { require more than } 1 \\
\text { material to be made } \\
\text { from in my worksheet. }\end{array}$ \\
\hline 5 & $\begin{array}{l}\text { Combine with idea } \\
\text { suggested in (4.) to conduct } \\
\text { cross-subject teaching. } \\
\text { - Use art lesson to allow } \\
\text { pupils to create drawings } \\
\text { of items with materials } \\
\text { indicated. }\end{array}$ & Agree & $\begin{array}{l}\text { Cross subject teaching, } \\
\text { allows total immersion in } \\
\text { topic being taught. }\end{array}$ & $\begin{array}{l}\text { I could specify in my } \\
\text { closing comments that } \\
\text { pupils are given time } \\
\text { during their art class to } \\
\text { draw out their } \\
\text { impression of items } \\
\text { being made from } \\
\text { unsuitable materials. }\end{array}$ \\
\hline
\end{tabular}

Overall, we found that a majority of the students' postings in both online discussions I and II represented in depth critical thinking. More specifically, in the first online discussion activity, $20 \%$ of the postings were surface level, and $80 \%$ were in depth postings. In the second online discussion, $47 \%$ of the posting were surface and $54 \%$ were in depth postings. The results indicated students were more critical in the online discussion when they did not know the identity of the designers. Examples of students' postings that show the levels of critical thinking are given in Table 5.

The second advantage is that no one student dominated the online discussion. This was because everyone could post any idea any time. Third, by reading the online postings, the tutor could identify misconceptions by the students when they applied their learned concepts and theories to critique others.

However, it is important to note that there are certain situations in which asynchronous online discussion activity 1 needs to be eliminated. First, the instructor 
may be teaching the course for the first time or the course is a newly developed one, hence the instructor does not have any previous student projects to show. Second, the nature of the new assignment has changed. Consequently, showing students the previous projects may no longer be relevant. In the last 12 years, we eliminated asynchronous online discussion activity 1 when one of the above situations arose.

Table 5: Examples of students' postings showing surface and in depth critical thinking levels

\begin{tabular}{|c|c|}
\hline $\begin{array}{l}\text { Level of critical } \\
\text { thinking }\end{array}$ & Examples of postings \\
\hline \multirow[t]{2}{*}{ Surface } & $\begin{array}{l}\text { "I would like to suggest that for practicum to include the following: (i) Titles } \\
\text { from the previous years; (ii) Supervisor's Comment and: (iii) Where to locate } \\
\text { them in the library." }\end{array}$ \\
\hline & $\begin{array}{l}\text { (The above contribution is classified at the surface level as the participant did not offer } \\
\text { any justification as to why his suggestions are valid.) }\end{array}$ \\
\hline \multirow[t]{2}{*}{ Surface } & $\begin{array}{l}\text { "I agree that Mr J to provide familiar examples and non-examples of water } \\
\text { cycles to students when involving intellectual skills. Students can learn the } \\
\text { concept of water cycle more effective from these example". }\end{array}$ \\
\hline & $\begin{array}{l}\text { (The above contribution is classified at the surface level as the participant 'echoed' Mr } \\
\text { J's view. Note that the second statement 'Students can learn the concept of water cycle } \\
\text { more effective from these example' is a re-phrasing of Mr J's original message, hence, } \\
\text { the participant did not take the conclusion further by developing with relevant facts) }\end{array}$ \\
\hline \multirow[t]{2}{*}{ In depth } & $\begin{array}{l}\text { "I would like to suggest using some video clips of WW2 epics on S'pore to } \\
\text { visualize the events. This will focus students' attention on the desired to-be- } \\
\text { learned features (Peters \& Daiker, 1982)" }\end{array}$ \\
\hline & $\begin{array}{l}\text { (This contribution is classified at the in-depth level as the participant managed to } \\
\text { justify his judgment) }\end{array}$ \\
\hline \multirow[t]{2}{*}{ In depth } & $\begin{array}{l}\text { "I agree with the removal of the } 5 \text { navigation buttons. The explanation is the } \\
\text { information/ instructions appear to be fairly linear within the PowerPoint, (and) } \\
\text { additional location buttons do not enhance navigation" }\end{array}$ \\
\hline & $\begin{array}{l}\text { (This contribution is considered as in depth critical thinking since the participant } \\
\text { stated that he shared a prior view by a fellow participant and supported the view with } \\
\text { his personal comment and experience.) }\end{array}$ \\
\hline
\end{tabular}

\section{Evaluation of Model 2's effectiveness from the students' perspective}

For Model 2, students made comments about in terms of the asynchronous online discussion and reflection table. In our earlier study (Cheung \& Hew, 2004), we collected students' perspective about asynchronous online discussion activity. The data were collected from students' responses to questionnaires, open ended questions, and focus group interviews. In general, they were favourable toward using asynchronous online discussion activity. They pointed out there were several benefits of using asynchronous online discussion:

- Flexibility and convenience,

- Increased reflection,

- Opportunity to express thoughts more freely and descriptively,

- Easy and permanent access to other people's ideas.

On the other hand, they also pointed out three limitations in using asynchronous online discussion activity, namely: 
- Procrastination or failure to respond to messages,

- Hard to express some ideas clearly in words,

- Posting messages simply for the sake of participation.

In the same study (Cheung \& Hew, 2004), students agreed that doing the reflection (see Table 3) was a good way to help them improve their design projects. This was because they had to look through all the discussion ideas carefully and make the decision whether to accept or reject each idea discussed in the online discussion. By completing the reflection table, each student was compelled to reflect and consolidate all the suggestions. The following two comments showed the importance of the reflection in Model 2 to improve their projects (Cheung \& Hew, 2004, p.220):

Student A: It [the reflection table] is a very good exercise because we have to look through every point that is raised by our classmates. We then have to consider whether to accept or reject the points made.

Student B: If I wasn't asked to do this [reflection], I would most probably not be selfreflecting when I looked through the project.

\section{Contributions of Model 2}

There are four major contributions of Model 2. First, the model provides an effective approach for teachers to know student understanding of the design principles before the students begin to design their projects. This is because a teacher can identify his or her students' understanding of the design concepts and theories in face to face discussion activities, as well as through the asynchronous online discussions of previous students' projects. The face to face and online discussion activities serve as a formative evaluation of students' understand of the design principles. Second, the asynchronous online discussion activities provide the teacher and students an effective and flexible way to interact with each other (i.e., the anytime and anywhere approach), that many students desire (McCray, 2000; Strambi \& Bouvet, 2003; Wingard, 2004). We believe this additional communication channel (i.e., asynchronous online discussion) provides a greater opportunity for students to exchange ideas, co-construct knowledge, and do self-reflections. In other words, Model 2 could enhance the accessibility of student learning.

Third, students could develop critical thinking skills. They have the time to think about the comments and suggestions before they reply to each other. In addition, they have to evaluate all the suggestions and consolidate them into a reflection table. This gives students time to think critically about all the suggestions and comments. Finally, besides helping students develop critical thinking skills, Model 2 is also able to support four critical, ill-structured problem solving processes (Jonassen, 1997): (a) articulating the problem space, (b) generating possible problem solutions, (c) assessing the viability of alternative solutions, and (d) monitoring the problem space and solution options. More specifically, the use of online discussion is able to support the first two processes, while the reflection table facilitates the last two processes (Cheung \& Hew, 2004).

\section{Comments and lessons learned from both blended models}

In this section, we describe some of the key lessons learned from using the two blended models. First, students have more satisfaction when they really understand the purpose of the use of asynchronous discussion. The use of asynchronous online 
discussion has to add value to the students' learning. It is not enough to merely reward the students with online participation marks because some students may end up playing the "assessment game". Students have to see that participating in the online discussion will contribute directly to the improvement of their learning and project work, in order to appreciate its use.

Second, before an online discussion, the instructor has to provide 'warm up' online activities to the students, to ensure that they know how to use the online discussion platform, and understand the meaning of online discussion. Instructors have to prepare the students before they begin the first online discussion activity; otherwise, they may not participate sufficiently often.

Third, when students served as the online facilitators, the tutors might spend less time in facilitating the discussion. Students learn both the content of the discussed topic and online facilitation skills.

Fourth, instructors have to train students to be online facilitators before they facilitate their own forums. As online facilitators, students have to use various facilitation skills to engage their peers in contributing to their forums. Table 6 lists some of these skills.

Fifth, instructors may consider using anonymity to encourage students to interact and provide feedback. We found that participants are more likely to take part in asynchronous online discussion forum when the identity of the owners of the objects under critique are kept unknown (anonymous) as compared to when the object owners are identified (Cheung et al., 2009). We also observed that when there is anonymity, participants tend to post notes that attain an in depth level of critical thinking (Cheung et al., 2009). One possible legitimate concern that instructors may have about the use of anonymity is the occurrence of aggressive and malicious behaviour such as flaming (Bertera \& Littlefield, 2003). However, we found no evidence for this in our earlier study (Cheung et al., 2009). We believe that incidences of malicious behaviour may occur more frequently in online public forums, rather than in an institutional courserelated discussion forum, because in the latter, the participants are anonymous only to their peers but not to the instructor. This creates a sense of accountability on the part of the participants to be responsible in their posting of comments.

\section{Future developments for both blended models}

In the future, we plan to further develop our blended models. First, we intend to use an audio based, asynchronous online discussion activity to replace the text based asynchronous online discussion activity. The use of audio based discussion could be very useful to students with weak reading or writing abilities. Furthermore, the availability of tonal cues may help the receiver better understand a sender's postings. This could minimise potential misunderstandings of meanings inherent in text based discussions.

Second, we plan to carry out future studies to evaluate further the effectiveness of the two blended learning models. Hew, Liu, Martinez, Bonk and Lee (2004) suggested that educators could evaluate the effectiveness of an online or blended learning approach at three levels: (a) macro-level, referring to the evaluation of entire online/ blended programs; (b) meso-level, referring to the evaluation of individual online/ blended courses; and (c) micro-level evaluation, referring to the evaluation of individual 
online/ blended student's learning. So far, our efforts have focused mainly on the meso- and micro-level evaluations. We plan to conduct macro-level evaluation to address questions including: (1) Is the blended-learning program, on the whole, cost effective? and (2) Can a positive return on investment be shown for the fiscal costs?

Table 6: Description of activity related to the organisational, social and intellectual facilitation types (extracted from Cheung \& Hew, 2005, pp. 58-59)

\begin{tabular}{|c|c|c|}
\hline \begin{tabular}{|l} 
Facilitation type \\
\end{tabular} & Description of activity & Source \\
\hline \multirow[t]{5}{*}{ Organisational } & $\begin{array}{l}\text { Spur participation when it is lagging. For example, } \\
\text { request direct comments and responses to the issues } \\
\text { discussed. }\end{array}$ & Paulsen (1995) \\
\hline & $\begin{array}{l}\text { Require regular participation. For example, exhorting } \\
\text { students to post at least two messages per week. }\end{array}$ & $\begin{array}{l}\text { Klemm (1998); Paulsen } \\
\text { (1995) }\end{array}$ \\
\hline & $\begin{array}{l}\text { Prompt frequently. Use private messages to urge } \\
\text { participants to take part in the discussion, to initiate } \\
\text { debates, and to solicit suggestions. }\end{array}$ & Paulsen (1995) \\
\hline & $\begin{array}{l}\text { Encourage participants to respond to each other as well } \\
\text { as to the tutor. }\end{array}$ & Salter (2000) \\
\hline & Keep discussion on track. & $\begin{array}{l}\text { Winiecki \& Chyung } \\
\text { (1998) }\end{array}$ \\
\hline \multirow[t]{2}{*}{ Social } & $\begin{array}{l}\text { Be responsive. For example, respond quickly to every } \\
\text { contribution either by posting a personal message to } \\
\text { the contributor or by referring to the author's comment } \\
\text { in the discussion. }\end{array}$ & Paulsen (1995) \\
\hline & $\begin{array}{l}\text { Reinforce good discussant behaviours. For example, } \\
\text { praise students who respond effectively online. }\end{array}$ & \\
\hline \multirow[t]{4}{*}{ Intellectual } & Ask questions to help participants understand. & $\mathrm{O}^{\prime}$ Grady (2001) \\
\hline & $\begin{array}{l}\text { Challenge ideas or opinions. Draw attention to } \\
\text { opposing perspectives, different directions or } \\
\text { conflicting opinions. }\end{array}$ & $\begin{array}{l}\text { Paulsen (1995); } \\
\text { Goodyear, Salmon, } \\
\text { Spector, Steeples \& } \\
\text { Tickner (2001); Berge } \\
\text { (1995) }\end{array}$ \\
\hline & Make appropriate contributions. & Goodyear et al. (2001) \\
\hline & $\begin{array}{l}\text { Insist that opinions posted by participants are } \\
\text { supported with data and rational reasoning. }\end{array}$ & Klemm (1998) \\
\hline
\end{tabular}

Third, we plan to allow students to access the online discussion activities through mobile devices such as smart phones (e.g., iPhones), and tablet computers (e.g., iPads). This will give students greater opportunities to contribute to the discussion activities. Bonk, Kim and Zeng (2006) envisioned future blended learning as increasingly involving hand held mobile devices, particularly mobile phones, with which a student can call up the learning that is needed or demanded (Wagner, 2006). Very likely, the use of these kinds of devices can make learning even more accessible for a wider spectrum of students, thereby fostering greater opportunities for lifelong learning (Keegan, 2002).

Fourth, we intend to ask students carry out their reflections by using blogs. This will allow students to read each others' blog so that they may learn from each other. In a recent review of the literature on blogs, Sim and Hew (2010) found that most students would like to use blogs more often as a learning tool, and that they would participate in the use of blogs for instruction after the course (Williams \& Jacobs, 2004; Zeng \& Harris, 2005). 


\section{Conclusions}

In this article, we shared two blended models used in NIE in the last twelve years. We integrated asynchronous online discussion activities with face to face tutorials for different reasons. In Model 1, the two main purposes for the online discussion activity are to allow students to gain in depth understanding about the use of the online facilitation skills, and to generate more ideas/ strategies for their projects. Students' reflection data confirmed that the two purposes have been achieved.

For Model 2, the main purpose of online discussion I is to allow students to apply what they learnt from the face to face tutorial and/ or reading materials to critique previous student projects. This serves as a form of formative assessment. The purpose of online discussion II, as well as the reflections, is help students to develop their own projects.

We believe there are many ways to integrate technology tools into face to face tutorials. We shared the two models to show our attempts at exploring the potential of the blended learning approach.

\section{References}

Almasi, J. F. (1996). A new view of discussion. In L. B. Gambrell \& J. F. Almasi (Eds.), Lively discussions: Fostering engaged reading (pp. 2-24). Newark, DE: International Reading Association.

Anderson, L. \& Krathwohl, D. (2001). A taxonomy of learning, teaching and assessing: A revision of Bloom's taxonomy of educational objectives. New York: Addison Wesley Longman.

Berge, Z. L. (1995). Facilitating computer conferencing: Recommendations from the field. Educational Technology, 35(1), 22-30.

Bertera, E. M. \& Littlefield, M. B. (2003). Evaluation of electronic discussion forums in social work diversity education: A comparison of anonymous and identified participation. Journal of Technology in Human Services, 21(4), 53-71. http: / / dx.doi.org/10.1300/J017v21n04_04

Bonk, C. J., Kim, K-J. \& Zeng T. (2006). Future directions of blended learning in higher education and workplace settings. In C. J. Bonk \& C. R. Graham (Eds), The handbook of blended learning: Global perspectives, local designs (pp. 550-567). San Francisco, CA: Pfeiffer Publishing.

Borup, J., Graham, C. R. \& Velasquez, A. (2011). The use of asynchronous video communication to improve instructor immediacy and social presence in a blended learning environment. In A. Kitchenham (Ed), Blended learning across disciplines: Models for implementation (pp. 38-47). Hershey PA: Information Science Reference.

Cheung, W. S. \& Hew, K. F. (2004). Evaluating the extent of ill-structured problem solving process among pre-service teachers in an asynchronous online discussion and reflection log learning environment. Journal of Educational Computing Research, 30(3), 197-227. http: / / dx.doi.org/10.2190/9JTN-10T3-WTXH-P6HN

Cheung, W. S. \& Hew, K. F. (2005). Factors affecting learners' satisfaction on the use of asynchronous online discussion in a hypermedia design environment. Journal of Southeast Asian Education, 5(1\&2), 56-70.

Cheung, W. S. \& Hew, K. (2007). Use of ground rules and guidelines in online discussion: A case study. In C. Montgomerie \& J. Seale (Eds.), Proceedings of World Conference on Educational Multimedia, Hypermedia and Telecommunications 2007 (pp. 2753-2758). Chesapeake, VA: AACE. http: / / editlib.org/p/ 25760 
Cheung, W. S., Hew, K. F. \& Foo, A. (2009). Examining the impact of object owners' anonymity on learners' participation rate and critical thinking in an asynchronous online discussion environment. In L. Cameron \& J. Dalziel (Eds.), Proceedings of the 4th International LAMS and Learning Design Conference (pp. 48-53). Sydney, Australia: LAMS Foundation.

Dziuban, C. D., Hartman, J. L. \& Moskal, P. D. (2004). Blended learning. Educause Center for Applied Research (ECAR) Research Bulletin, 7. [viewed 9 Nov 2011] http: / / net.educause.edu/ir/library/pdf/ERB0407.pdf

Dziuban, C., Hartman, J., Juge, F., Moskal, P. \& Sorg, S. (2006). Blended learning enters the mainstream. In C. J. Bonk \& C. R. Graham (Eds), The handbook of blended learning: Global perspectives, local designs (pp. 195-208). San Francisco, CA: Pfeiffer Publishing.

Fenton, D. \& Watkins, B. W. (2010). Fluency in distance learning. Charlotte, NC: Information Age Publishing, Inc.

Goodyear, P., Salmon, G., Spector, J. M., Steeples, C. \& Tickner, S. (2001). Competences for online teaching: A special report. Educational Technology Research and Development, 49(1), 65-72. http: / / dx.doi.org/10.1007/BF02504508

Graham, C. R. (2006). Blended learning systems: Definition, current trends, and future directions. In C. J. Bonk \& C. R. Graham (Eds), The Handbook of blended learning: Global perspectives, local designs (pp. 3-21). San Francisco, CA: John Wiley \& Sons, Inc.

Hew, K. F. \& Cheung, W. S. (2003). Evaluating the participation and quality of thinking of preservice teachers in an asynchronous online discussion environment: Part 1. International Journal of Instructional Media, 30(3), 247-262. http: / www.highbeam.com/doc/1G1109083264.html

Hew, K. F., Cheung, W. S. \& Ng, C. S. L. (2010). Student contribution in asynchronous online discussion: A review of the research and empirical exploration. Instructional Science, 38(6), 571-606. http: / / dx.doi.org/10.1007/ s11251-008-9087-0

Hew, K. F. \& Knapczyk, D. (2007). Analysis of ill-structured problem solving, mentoring functions, and perceptions of practicum teachers and mentors toward online mentoring in a field-based practicum. Instructional Science, 35(1), 1-40. http: / / dx.doi.org/10.1007/s11251006-9000-7

Hew, K. F., Liu, S., Martinez, R., Bonk, C. \& Lee, J. Y. (2004). Online education evaluation: What should we evaluate? In the Proceedings of the Association for Educational Communications and Technology (pp. 243-246). Chicago, IL: Association for Educational Commnications and Technology. http:/ / www.eric.ed.gov / PDFS / ED485142.pdf

Hung, W. L., Chen, D. \& Cheung, W. S. (1998a). Fostering critical and creative thinking through classroom discourse: The GNOSIS framework. Teaching $\mathcal{E}$ Learning, 19(1), 1-9. http:/ / repository.nie.edu.sg/jspui/ bitstream/10497/371/1/TL-19-1-1.pdf

Hung, W. L., Chen, D. \& Cheung, W. S. (1998b). Fostering critical and creative thinking through the GNOSIS process. In M. L. Quah \& W. K. Ho (Eds.), Proceedings of the 7 th International Conference on Thinking 1997 (pp. 258-266). Singapore: Prentice Hall.

Jonassen, D. H. (1997). Instructional design models for well-structured and ill-structured problem solving learning outcomes. Educational Technology Research E Development, 45(1), 6594. http: / / dx.doi.org/10.1007/BF02299613

Keegan, D. (2002). The future of learning: From elearning to mlearning. Hagen, Germany: Fern University Institute for Research into Distance Education. 
Klemm, W. R. (1998). Eight ways to get students more engaged in online conferences. T.H.E. Journal, 26(1), 62-64. http:/ / thejournal.com/articles/1998/08/01/ eight-ways-to-getstudents-more-engaged-in-online-conferences.aspx

McCray, G. E. (2000). The hybrid course: Merging on-line instruction and the traditional classroom. Information Technology and Management, 1(4), 307-327. http: / dx.doi.org/10.1023/ A:1019189412115

Murphy, E. \& Coleman, E. (2004). Graduate students' experiences of challenges in online asynchronous discussions. Canadian Journal of Learning and Technology, 30(2). http: / / www.cjlt.ca/index.php/cjlt/article/view/128/122

O'Grady, G. K. (2001). Maximising the potential of computer mediated discussion: Guidelines for facilitation. Centre for Development of Teaching and Learning (CDTL) Brief, 4(4). http:// www.cdtl.nus.sg/Brief/v4n4/ sec3.asp [viewed 1 Sep 2011].

Oliver, M. \& Shaw, G. P. (2003). Asynchronous discussion in support of medical education. Journal of Asynchronous Learning Networks, 7(1), 56-67. http:// sloanconsortium.org/sites/default/files/v7n1_oliver_1.pdf

Paulsen, M. F. (1995). Moderating educational computer conferences. In Z. L. Berge \& M. P. Collins (Eds.), Computer mediated communication and the online classroom: Vol. 3. Distance Learning (pp. 81-89). Cresskill, NJ Hampton Press, Inc.

Reay, J. E. (2001). Blended learning - A fusion for the future. Knowledge Management Review, 4(3), 6.

Rooney, J. E. (2003). Blended learning opportunities to enhance educational programming and meetings. Association Management, 55(5), 26-32.

Romiszowski, A. \& Mason, R. (2004). Computer-Mediated Communication. In D. Jonassen (Ed), Handbook of research on educational communications and technology (pp. 397-431). Mahwah, NJ: Lawrence Erlbaum Associates, Publishers.

Salter, G. (2000). Making use of online discussion groups. Australian Educational Computing, 15(2), 5-10. http: / / acce.edu.au/journal/15/2/making-use-online-discussion-groups

Sim, J. W. S. \& Hew, K. F. (2010). The use of weblogs in higher education: A review of empirical research. Educational Research Review, 5(2), 151-163. http: / / dx.doi.org/10.1016/j.edurev.2010.01.001

Strambi, A. \& Bouvet, E. (2003). Flexibility and interaction at a distance: A mixed-mode environment for language learning. Language Learning and Technology, 7(3), 81-102. http: / /lt.msu.edu/vol7num3/pdf/strambi.pdf

Vygotsky, L. S. (1978). Mind in society. Cambridge, MA: Harvard University Press.

Wagner, E. D. (2006). On designing interaction experiences for the next generation of blended learning. In C. J. Bonk \& C. R. Graham (Eds), The handbook of blended learning: Global perspectives, local designs (pp. 41-55). San Francisco, CA: Pfeiffer Publishing.

Williams, J. B. \& Jacobs, J. (2004). Exploring the use of blogs as learning spaces in the higher education sector, Australasian Journal of Educational Technology, 20(2), 232-247. http:/ / www.ascilite.org.au/ajet/ajet20/williams.html

Wingard, R. G. (2004). Classroom teaching changes in web-enhanced courses: A multiinstitutional study. EDUCAUSE Quarterly, 27(1), 26-35. http:/ / net.educause.edu/ir/library/pdf/EQM0414.pdf 
Winiecki, D. J. \& Chyung, Y. (1998). Keeping the thread: Helping distance education students and instructors keep track of asynchronous discussions. In Proceedings of the 14th Annual Conference on Distance Teaching \& Learning (pp. 451-460). Madison, WI: University of Wisconsin-Madison.

Wong, K. M., Hew, K. F. \& Cheung, W. S. (2009). The impact of the use of classroom response pad system on the learning of secondary school physics concepts: A Singapore quasiexperiment study. British Journal of Educational Technology, 40(5), 848-860. http: / dx.doi.org/10.1111/j.1467-8535.2008.00868.x

Zeng, X. \& Harris, S. T. (2005). Blogging in an online health information technology class. Perspectives in Health Information Management, 2(6). [viewed 6 Oct 2009]. http: / / www.ncbi.nlm.nih.gov/ pmc/articles / PMC2047310/ ?tool=pubmed

Authors: Dr Wing Sum Cheung

Associate Professor, Learning Sciences \& Technologies

National Institute of Education, Nanyang Technological University

1 Nanyang Walk, Singapore 637616, Singapore

Email: wingsum.cheung@nie.edu.sg

Web: http:/ / www.nie.edu.sg/profile/ cheung-wing-sum

Dr Khe Foon Hew

Assistant Professor, Learning Sciences \& Technologies

National Institute of Education, Nanyang Technological University

1 Nanyang Walk, Singapore 637616, Singapore

Email: khefoon.hew@nie.edu.sg Web: http:/ / www.nie.edu.sg/profile/hew-khe-foon

Please cite as: Cheung, W. S. \& Hew, K. F. (2011). Design and evaluation of two blended learning approaches: Lessons learned. In Hong, K. S. \& Lai, K. W. (Eds), ICT for accessible, effective and efficient higher education: Experiences of Southeast Asia. Australasian Journal of Educational Technology, 27(Special issue, 8), 1319-1337.

http: / / www.ascilite.org.au/ajet/ajet27/ cheung.html 